Mariya Kascha,

Sumy State University, Ukraine

(D) ORCID http://orcid.org/ 0000-0001-9055-8304

e-mail:m.kascha@uabs.sumdu.edu.ua

Maksym Palienko,

PhD, Italy

Roman Marchenko,

Sumy State University, Ukraine

(1) ORCID https://orcid.org/0000-0002-0716-3078

e-mail: r.marchenko@student.sumdu.edu.ua

Correspondence author: e-mail: m.kascha@uabs.sumdu.edu.ua

\title{
FORECAST OF COVID-19 PROGRESS CONSIDERING THE SEASONAL FLUCTUATIONS
}

Abstract. This study aims to analyze the course of the COVID-19 disease and forecast its progress. Systematization of scientific background concerning the issues under investigation indicated the snowballing growth of scientific publications devoted to COVID-19. The urgency of the research rests on the negative influence of the SARS-CoV-2 virus on all spheres that deepen the global economic crisis. The forecast of the COVID-19 progress in Ukraine was carried out in the following logical sequence: 1) collection and analysis of statistical data; 2) testing stationarity and periodicity of the time series, using software Statistica (portable); 3) constructing the trend component 4) detecting the seasonal component by the fast Fourier transformation under excluded trend; 5) building the general model, checking its quality and adequacy; 6 ) forecast and elaboration on the recommendations. The methodological tools of the study were the regression and correlation analysis, the Dickie-Fuller test, decomposition of the additive model into cyclic and trend components, and the fast Fourier transformation, using software MathCAD(portable). The empirical research was conducted based on panel data from 22 January 2020 to 2 May 2021. The object of the study was selected the population of Ukraine who were infected with coronavirus during the study period. The study empirically confirmed and theoretically proved that if the pandemic tendency persists and the absence of carefully planned COVID-19 preventive work in Ukraine, a new wave of the disease may occur from mid-August to early September. Besides, the growth of the load on the medical sector and the increase in COVID-19 deaths among the population may lead to the introduction of new restrictive quarantine measures. In turn, it would result in an economic shutdown and the decline of small and medium businesses. Therefore, it is necessary to direct the Government's policy to eliminate the myths about vaccination, to increase confidence in vaccination among the population, which will avoid the next wave of diseases.

Keywords: COVID-19, fast Fourier transformation, stationarity, Dickie-Fuller test, morbidity, harmonic analysis, trend-seasonal model, forecast.

Introduction. The COVID-19 pandemic unveiled the weaknesses of the world economy and medicine. Thus, the enterprises' shutdown transformed the country's economy against a severe quarantine and two lockdowns in one year. Therefore, it is vital to study the infection rate for its prevention.

The pandemic splash showed the Ukrainian health care system could hardly respond quickly to crises. Moreover, the low financial security of most municipal primary and secondary care facilities is reflected in low material support, etc. The crisis has revealed many problems in healthcare that long exist at the global, national, regional, and local levels. Nowadays, it is necessary to provide more insights on public health, the resource state and technological support of healthcare facilities, access to health care (physical, financial), and its quality at all levels. It would allow a more effective deal with possible epidemiological disasters.

Another essential element in assessing the situation in the health sector is the lack or

Cite as: Kascha, M., Palienko, M., \& Marchenko, R. (2021). Forecast of COVID-19 Progress Considering the Seasonal Fluctuations. Health Economics and Management Review, 2, 71-82. http://doi.org/10.21272/hem.2021.2-07

71 
underdevelopment of scientific and methodological approaches to identify critical areas for new strategic action. It is essential to conduct in-depth and detailed statistical analysis to identify patterns for further forecasting the regional health care systems and other decisions on resource provision.

The research aims to develop an economic and mathematical model for predicting the COVID-19 incidences (as an example of Ukraine) to detect and prevent epidemiological threats on time.

Literature Review. The systematization of the treatises showed the researchers take a keen interest in COVID-19. Remarkably, the primary concern is investigating how to overcome the negative pandemic influence that transforms the world economy, medicine, environment, education, etc. On the other hand, the researchers work on the causal relationships between differentiated vulnerabilities of different countries (or regions within one country) and the state of social, environmental, and economic spheres. Thus, many scientists conducted a cluster analysis to divide all countries by vulnerability groups from the effects of the pandemic.

An analysis of the modern academic literature showed that scientists worldwide are getting more interested in pandemic issues. They cover a wide range of research topics related to COVID-19. However, a study in medicine and pharmaceuticals is a priority in combatting the COVID-19 disease. The global economic crisis forces economists worldwide to focus on estimating the losses, possible options for mitigating the negative effects and finding cause-effect relationships of differential impact. Notably, there is a special mention of forecasting future scenarios for early prevention.

Although the study (Dutta et al., 2020) was conducted at the beginning of the pandemic (April 2020), the findings showed the rapid growth of news address pandemics. Indeed, the spread of COVID-19 worldwide has changed the research directions worldwide. For example, in the study (Açikgöz and Günay, 2020), the authors emphasized that the world economy has undergone significant changes due to the pandemic and would not return to its previous state. The authors introduced several possible economic and political scenarios for national and international development. In turn, Boettke and Powell (2021) explained the political mistakes made by governments worldwide in controlling pandemics. It is emphasized that at the very pandemic beginning, decision-makers did not fully realize the converging threat. Thus, they did not persuade the infected to be responsible to society. In the study (Sandbrook et al., 2020), the authors proposed four long-run alternative scenarios to recover the world economy and eliminate obstacles to stable economic growth, «green» economic recovery, or reconstruction. Besides, they emphasized the necessity to prioritize between rapid production development or environmental issues.

Tommaso (2020) considered the pandemic impact on the Italian economy. The findings showed that Italy could mitigate the negative effects of economic crises only through coordinated international action. The research (Bond et al., 2020) concluded that the current economic state provokes new long-run business solutions worldwide. The high technologies, particularly remote or cloud technologies, are closely integrated into modern life due to quarantine restrictions. The pandemic set heavy conditions for business. It acted as a catalyst for implementing new business ideas, which a few years ago were considered fantastic. The study (Power, 2020) addressed the public's increasing burden on the care economy, mostly domestic and unpaid worldwide. Due to quarantine restrictions worldwide, many workers switched to distance work, children to homeschooling, which increased the workload of both physical and mental work. The authors insisted on reviewing and considering changes in the distribution of social protection of the above population segments. In Brodeur et al. (2020), the authors reviewed many modern scientific papers on the pandemic influence on the economy. They systematized the scientific background on various areas of social, environmental, discrimination and employment in quarantine.

Cutler (2020) considered the healthcare recession. Despite increasing subsidies to healthcare worldwide, they focus on overcoming the SARS-CoV-2 virus. However, there are gaps in primary and secondary health care. Besides, McKee and Stuckler (2020) emphasized that the COVID-19 pandemic is 
primarily a medical crisis. Any economic crisis has resulted from deteriorating public health. However, this situation is the opposite. The COVID-19 pandemic revaluated the social values. Notably, the healthcare and social spheres were depreciated for a long time. Therefore, it resulted in an explosion of negative consequences around the world. The authors provide several examples of reassessing the priorities of society's development after economic crises. Besides, they focused on health, social protection, and the environment throughout the civilized world. The study (Nishi et al., 2020) addressed finding the best option for life routine amid a pandemic. The authors elaborated on the mechanism to balance social slowdown, staying at home, and economic activity. Thus, they proposed two social activity strategies: dividing society into groups depending on the time of day and the other - restrictions on people being in one place simultaneously. The scientists emphasized that only following both strategies could guarantee the most significant effect in combating the virus.

Ozili and Arun (2020) empirically proved the negative impact of quarantine restrictions on economic activity in stock markets. The researchers supposed that the global stock market transformed because of the instability of shares. As a result, most investors have transferred their assets to more stable and reliable projects. The study (Gershon et al., 2020) proposed the current and possible pandemic scenarios. The authors insisted on declining economic interruption and quarantine restrictions while focusing on healthcare development. In the study, the authors suggested increasing the number of hospital beds and developing an isolation policy for contact people even during the incubation period. In turn, it would allow increasing the efficiency in combatting the virus. Besides, the findings showed that absolute and partial quarantine had the same effect if there is a healthcare load growth. Therefore, it leads to reflections on introducing the absolute quarantine.

Atalan (2020) considered the relationships between the number of days under which quarantine restrictions were applied, the restrictions strength, and the COVID-19 dynamics in 49 countries. The result showed that isolation could slow down the virus spread. Moreover, the lockdown has a positive effect on the environment and psychological aspects. The above studies show the opposite results. Therefore, it could be concluded that there are several tools for epidemiological crises with advantages and disadvantages.

Ray (2021) emphasized that the general rules for the whole world allow controlling the virus spread. In addition, developing a common effective scenario would help fight against other respiratory diseases. Therefore, it automatically reduces the burden on the medical sector and government spending in this area. Alkubaisy (2020) described the pandemic consequences based on the Gulf countries. Many projects in these countries have already faced a shortage of workforce and materials because of the curfew time and travel ban. In turn, it led to a long-term economic shutdown.

Tovmasyanv and Minasyan (2020) analyzed the influence of employee motivation on work efficiency during the pandemic. This issue becomes especially critical during the transition of most businesses to remote work. If in the past remote work was an advantage, nowadays the priorities have changed dramatically. Besides, the findings showed that employees and employers had different views concerning motivation. Lopez and Alcaide (2020) noted that quarantine restrictions provoked the transformation of different life spheres towards its digitalization. The scientists conducted an in-depth analysis on the high tech in the particular blockchain. It was noted that artificial intelligence methods are designed to help humanity in changing times and eliminate uncertainty in many areas. Keliuotytè-Staniulènienè and Daunaravičiūtè (2021) provided theoretical argumentation that the pandemic harmed the green investment market. On the other hand, Hinrichs and Bundtzen (2021) investigated the relationship between the insurance companies and the COVID-19 consequences. The findings highlighted that personal contact with the client is more effective than remote work.

It stands to mention that recent studies addressed mainly forecasting future pandemic scenarios, while the COVID-19 pandemic was not predicted. Therefore, the scientists aim to forecast new COVID-19 waves 
to help governments prepare in advance. Thus, Fanelli and Piazza (2020) analyzed and predicted the disease spread in Italy, France, and China, using the SIR (Susceptible-Infected-Recovered) model, recursive relationships, and nonlinear approximation. This model is adapted to study the regional epidemiological level. In this case, the entire population is divided into three groups: vulnerable to the disease, infected, or recovered.

In the study (Papastefanopoulos et al., 2020), the authors conducted the forecast on the COVID-19 incidences and deaths using the autoregressive integrated moving average model (ARIMA) and the additive Holt-Winters model. Notably, the ARIMA model is designed to consider local changes, removing white noise from the time series, using a linear correlation between the series levels. The model is often applied because it is easy to interpret. Moreover, it is easy to update the results with quite an accuracy. Notably, the ARIMA model uses only linear dependences. Therefore, before study the complex systems (analysis of the pandemic consequences considers the multifactorial and complexity of the system), results in approximation could malfunction. In turn, the additive Holt-Winters model uses exponential smoothing considering additive seasonality and trend. It stands to mention that exponential smoothing means the forecast revaluation considering the weighting coefficients of new data. Notably, the newer the observation is, the greater its weight for future scenarios is. The mandatory modeling step is to check the anomalous emissions for regularities. In turn, quite inaccurate results are the main disadvantages of this forecasting model. The study (De Livera et al., 2011) involved the TBAT model (T - trigonometric transformation, B Boxing transformation, A - ARIMA error, $T$ - trend). This model uses a trigonometric component to study seasonality, considering trends and normalization. This model is empirically tested and gives quite accurate results due to the seasonal time series decomposition. Moreover, the TBAT model allows identifying the seasonal components that are hardly visible on the chart. On the other hand, the model disadvantage is the complexity of the application. Thus, it is necessary to restart the whole procedure to update data.

Taylor and Letham (2018) provided a detailed description of the Prophet forecast model (developed for Facebook). Although applying this model in business is a disadvantage, many business solutions have features like many other industries that require forecasting. Mostly, this model is regressive but partly based on the Fourier series. The model's parameters are easy to interpret. Notably, this model consists of two parts:

1) the Saturation Growth Model corresponding to population growth models with nonlinearity elements. For building a forecast, the saturation point is never reached;

2) the piecewise-linear model. This model is easy to adjust to new circumstances, but it does not work well with default values.

The study (Salinas et al., 2019) used DeepAR probabilistic forecast based on recursive neural networks of short-term and long-term memories. Notably, the greater the network depth, the more accurate the result. The method's advantage is obtaining results in probabilistic predictions based on the Monte Carlo method. Besides, this model could work with minimal manual intervention.

Table 1. General specifications of approaches to forecasting the COVID-19 incidences

\begin{tabular}{|c|c|c|}
\hline Apprc & Advantages & Disadvantages \\
\hline Simulation mode & $\begin{array}{l}\text { SIR or SEIR Simple, considers the specific } \\
\text { forecasting the progress of COVID- } \\
\text { disease }\end{array}$ & $\begin{array}{l}\text {-No possibility to get different development } \\
\text {-19scenarios. Effective in combination with } \\
\text { other forecasting methods }\end{array}$ \\
\hline ARIMA & $\begin{array}{l}\text { Accurate, easy to update, interpret } t \\
\text { results }\end{array}$ & theOnly linear relationships are used \\
\hline $\begin{array}{l}\text { The additive } \\
\text { model }\end{array}$ & $\begin{array}{l}\text { Holt-WintersSimplicity, considering the importance } \\
\text { recent observations over older ones }\end{array}$ & ofLow accuracy \\
\hline TBAT & Sufficiently precise results & Difficulties in updating new data \\
\hline
\end{tabular}


Continued Table 1

\begin{tabular}{lll}
\hline Prophet & Easy to update & $\begin{array}{l}\text { Implementation complexity focused on } \\
\text { business }\end{array}$ \\
DeepAR & $\begin{array}{l}\text { Large range of probabilistic predictions } \\
\text { based on the Monte Carlo method }\end{array}$ \\
\hline
\end{tabular}

Sources: developed by the authors.

Table 1 presents the generalized description of the above methods. Thus, the forecasting issue is one of the most interesting and problematic among modern scientists. That is confirmed by a wide range of methods that have their disadvantages and advantages. When forecasting the future incidence of COVID19 , it is important to consider the industry specifics, trends, and seasonality. Many methods rest on the Fourier series, and the probabilistic component is implemented using the Monte Carlo method or neural networks.

Methodology and research methods. This study involved the harmonic analysis based on transforming the time series into a Fourier series, where the trend component was removed first.

Stage 1. For modeling and forecasting the phenomena associated with any epidemiological situation, it is necessary to consider the total number of infected and deaths per unit of time. Notably, mortality and morbidity are interrelated since the number of infected people affects the number of deaths caused by this disease and vice versa. However, there is a complexity with accounting mortality because this data could be nonobjective. For example, the cause of death is controversial. The person could die of COVID-19 complication or chronic disease, which was complicated with COVID-19. Therefore, it is a challenging question to determine the death case was COVID-19 or another disease. Thus, the indicator of the number of infected (Kobelev, 2000) was chosen in this study. However, this methodology is applicable for the number of COVID-19 death.

These data contain accumulated indicators that are irrational to predict. Therefore, the data reflecting differences in new diseases was created, i.e., an absolute chain growth (1).

$$
\Delta y=y_{n}-y_{n-1}
$$

The obtained time series consists of absolute growth of each level of the series for the number of patients with COVID-19. Further calculations involved the indicator «the number of new COVID-19 cases per day» from 22 January 2020 to 2 May 2021 (Fig. 1).

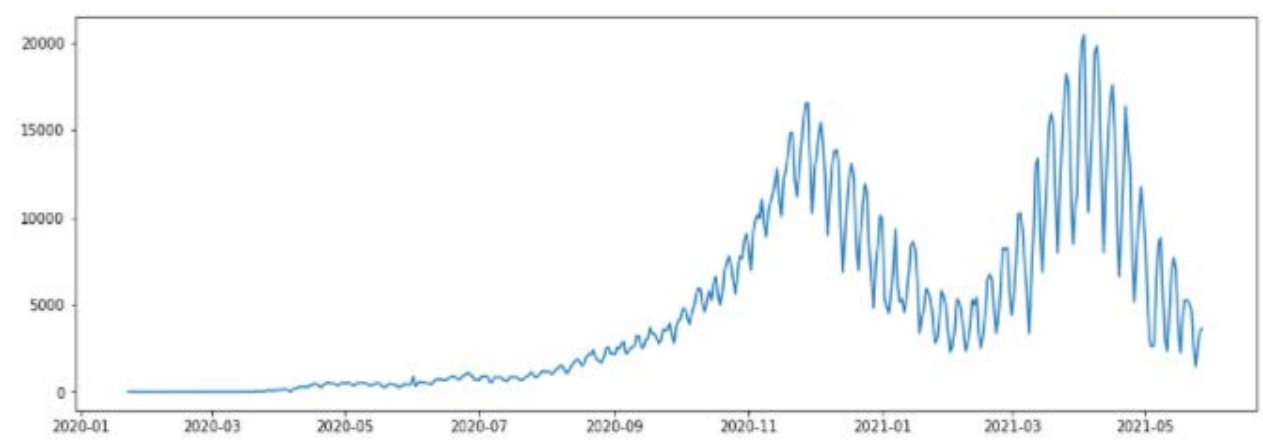

Figure 1. The new COVID-19 cases per day

Sources: developed by the authors based on (Worldometer, 2021). 
The virus progression in Ukraine showed that the number of COVID-19 cases gradually increased from January to September 2020. Since September, the number of infected had a rapid growth until its peak in December. Then, at the beginning of January, Ukraine introduced the lockdown. The number of patients gradually decreased until early March, when a new wave of morbidity began. Figure 2 shows the average distribution of patients with coronavirus disease by month and quarter. It is seen that the COVID19 peak was in winter. It is suggested that the winter COVID-19 growth was caused by increasing the number of carriers who transmitted the disease asymptomatically or detected it later. Therefore, the virus spread had an almost exponential increase.
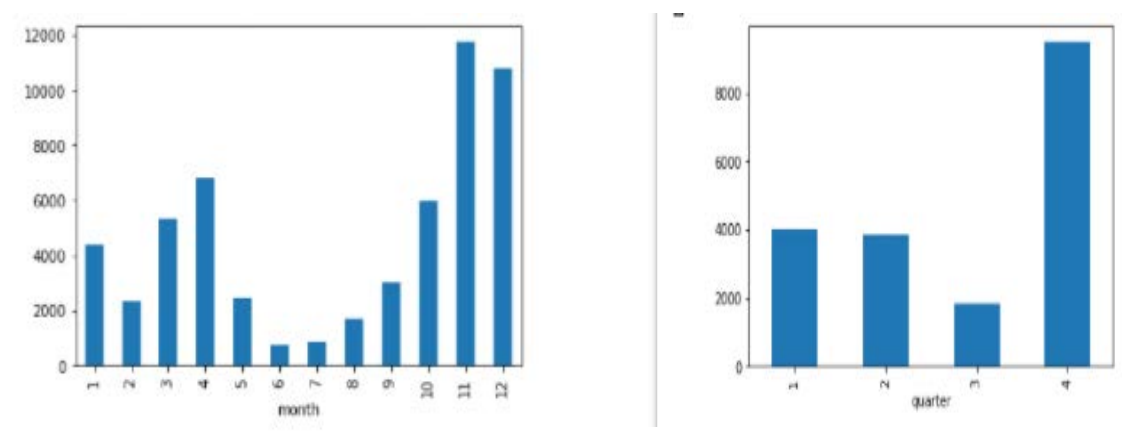

Figure 2. The average distribution of patients with coronavirus disease by month and quarter Sources: developed by the authors based on (Worldometer, 2021).

Stage 2 involved the stationery and periodicity tests of time series data. For testing the stationarity by an autoregressive time series model, the Dickey-Fuller test was used. The practical realization was done by using the software Python. Figure 3 visualizes the obtained results.

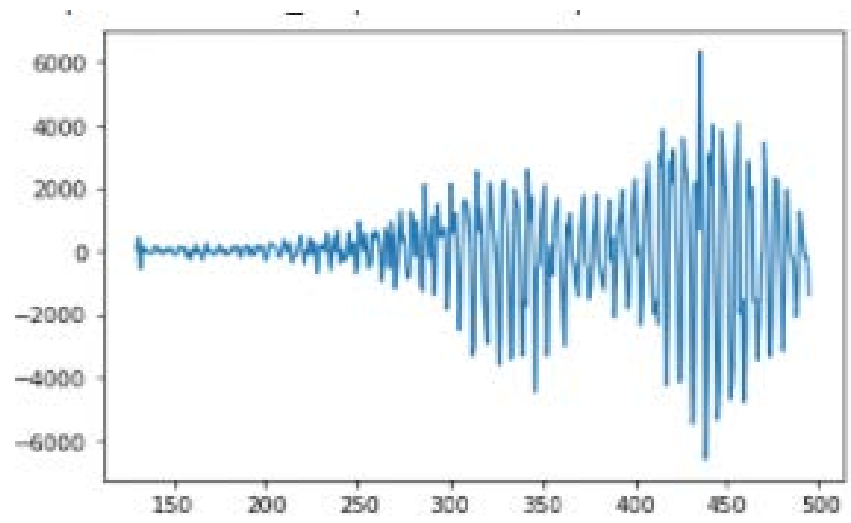

Figure 3. Stationarity check of data (Dickey-Fuller test)

Sources: the authors' calculation.

The time series is not stationary since the $p$-value is higher than $5 \%(p=14 \%)$. Therefore, it depends on the time and could be used for the forecast. Visual data analysis allows suggesting the periodicity in 
the investigated data set. Notably, if that is the case, a seasonal analysis could be conducted. Thus, the Spectral (Fourier) Analysis was conducted by software Statistica Portable to check the periodicity. Figure 4 demonstrates the obtained results. An acute angle indicates the presence of regular cycles, while the gentle ones mean irregular cycles. Therefore, the studied time series contains two regular cycles with a 7- and 125-days period. Besides, there is an irregular cycle with a frequency of 65 days.

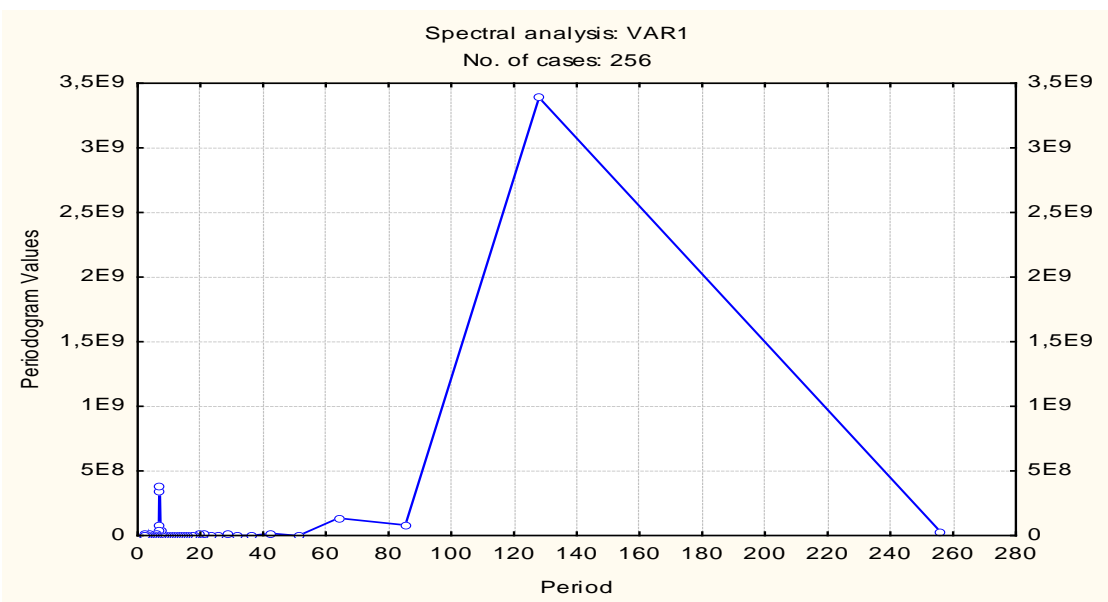

Figure 4. Periodogram results

Sources: developed by theauthors.

A 7-days cycle confirms that the number of PCR tests is less during the weekend. In turn, the 125days cycle is a seasonal wave of morbidity of 4 months without preventive vaccinations. Therefore, it could be suggested that if there is no preventive work to combat COVID-19, the next wave of cases would be repeated every 4 months.

Stage 3. Construction of the trend component of the time series provides using the linear trend (2). At this stage, it is necessary to determine the trend component and remove it from the model. Notably, the coefficients mean the value of average increasing $Y$ if $X$ increase by 1 . Thus, the following equation allows predicting the $\mathrm{Y}$ behavior concerning $\mathrm{X}$ changes:

$\mathrm{Y}=\mathrm{a}+\mathrm{bx}$

where $x$ - independent variable; $Y$ - dependent variabl; $a$ - absolute term (means $Y$ value, if $x=0$ ); $b$ - slope coefficient or gradient of the estimated line.

Stage 4. For analyzing the harmonic vibration, the MathCad software package was used. The result is the Fourier series expansion (3). The harmonic analysis (Fourier analysis) presents the time series as harmonic sums. It stands to note that, in general, the harmonic sum is not limited. However, as a rule, only significant harmonic sums reveal the most distinctive aspects of the time series.

$$
f(t)=\frac{a_{0}}{2}+\sum_{k=1}^{\infty} A_{k} \cos \left(k \frac{2 \pi t}{T}+\theta_{k}\right)
$$

where $\mathrm{f}(\mathrm{t})$ - seasonal component; $\mathrm{a}_{0}$ - absolute term; $\mathrm{k}$ - harmonic number; $\mathrm{A}_{\mathrm{k}}$ - amplitude of $\mathrm{k}$ fluctuation; $\frac{2 \pi t}{\mathrm{~T}}-$ frequency; $\theta_{\mathrm{k}}$ - phase of k-fluctuation. 
Thus, the harmonic analysis resolves to harmonics calculation by determining the most significant cyclic components equations. The feature of fast Fourier transformation is the second degree of data series levels. Thus, the last 256 days were taken from the whole data sample.

The input data was imported to the matrix W. The linear trend was calculated. Then, the graphs visualizing the data series, the trend, and the data series without trend were considered (4).

$$
Q_{j}:=M_{j}-Y_{j}
$$

where $\mathrm{Yj}$ - the equation of linear regression for the previous 256 days, Qj - an operator of calculation without trend.

The harmonics of the U-Fourier series were founded using the Fast Fourier transformation operator. Notably, among 128 harmonics, the significant ones were only three (the 2-nd, the 6-th, and the 37-th). The rest of the harmonics have less weight. Therefore, they were ignored in further research.

To study the cyclic component, the 2-nd, the 6-th, and the 37-th harmonics were considered. Then, the coefficients $\mathrm{Am}(5)$ and $\mathrm{Fq}(6)$ of the Fourier series were calculated, while the equation of the cyclic component was compared (3).

$$
\begin{aligned}
& \mathrm{Am}=\frac{\left|\mathrm{U}_{\mathrm{k}}\right|}{\mathrm{e}} \\
& \mathrm{Fq}=\arg \left(\mathrm{U}_{\mathrm{k}}\right)
\end{aligned}
$$

After examining the time series seasonality, the trend was returned to the model by adding equations (2) and (3). The obtained result is an additive model with the seasonal trend.

Results. Using the MS Excel software package, regression (7) was obtained. Hence it appears that there is a general tendency to increase the number of infected by 1.2 on average per day present. Besides, without seasonality, the existing number of infected per day exceeds 8000 cases.

$$
Y_{j}=1.2 j+8001.8
$$

Having converted the time series into a Fourier series and calculated the corresponding coefficients (5) and (6), the following result was got (8)

$$
\begin{aligned}
& f(t)=5021 \cos \left(\frac{1}{64} \pi x-0,51\right)+2536 \cos \left(\frac{9}{32} \pi x-1,17\right)+ \\
& +3059\left(\frac{37}{128} \pi t+1,2654\right)
\end{aligned}
$$

Then, the trend was returned to model (8). Thus, the obtained general formula predicted «the number of infected per day» for 256 days.

$$
\begin{aligned}
& f(t)=5021 \cos \left(\frac{2}{256} \pi x-0,51\right)+2536 \cos \left(\frac{36}{256} \pi x-1,17\right)+3059\left(\frac{37}{256} \pi t+\right. \\
& 1,2654)+1.2 j+8001.8
\end{aligned}
$$

Figure 5 visualizes the comparison of empirical results (blue) and theoretical values (red line), which were obtained using formula (9). 


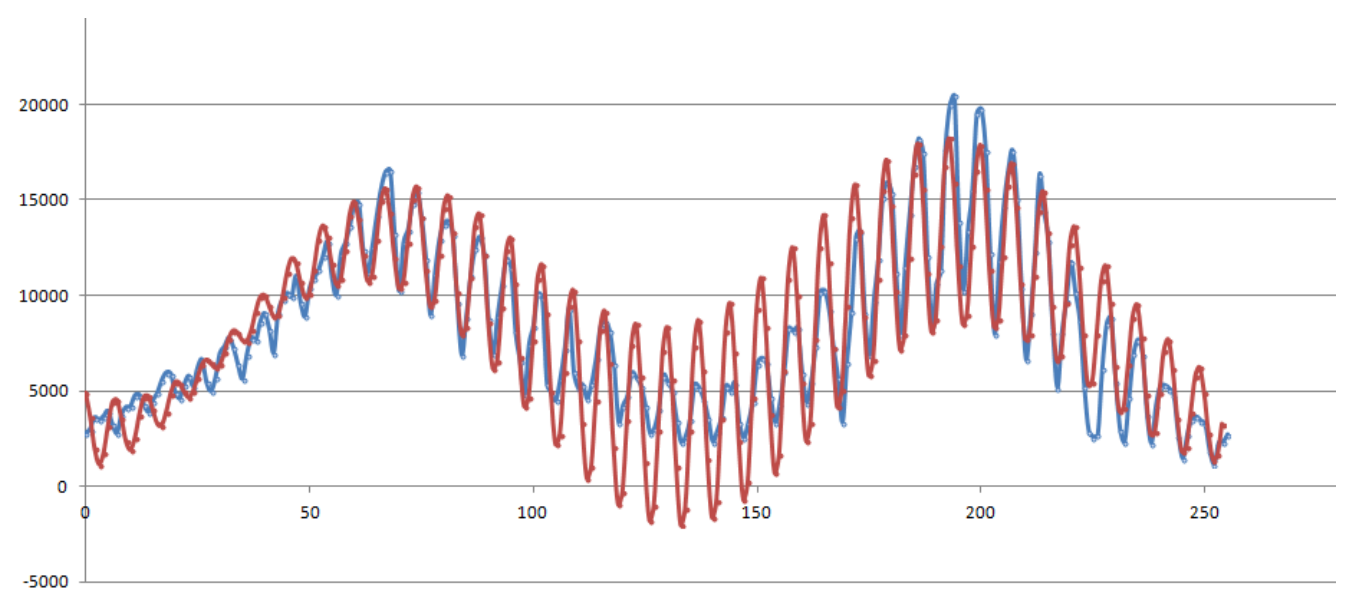

Figure 5. Matching theoretical and empirical data

Sources: developed by the authors.

To substantiate the model validity (9) to predict the level of COVID-19 incidence, the quality of the model was checked using the determination coefficient (10) and Fisher's criterion. It stands to note that determination coefficient $R^{2}$ indicates the factor variability described by the model as below:

$$
R^{2}=\frac{\sum_{1}^{256}\left(\widehat{\vartheta}_{i}-\bar{y}\right)^{2}}{\sum_{1}^{256}\left(y_{i}-\bar{y}\right)^{2}}
$$

where $y_{i}$ - empirical data used for investigation; $\hat{y}_{i}$ - theoretical data received with formula (9); $\bar{y}-$ average value of all levels.

The findings showed $R^{2}=0.91$. Thus, it indicates a high degree of model quality. Model (10) explains the $91 \%$-variability of the indicator "number of infected" depending on the day.

For testing the model quality, Fisher's criterion (11) was used. Notably, it indicates the statistical significance of the model.

$$
F=\frac{R^{2}}{1-R^{2}} \cdot \frac{n-m-1}{m}
$$

where $R^{2}$ - the coefficient of determination; $\mathrm{m}$ - the number of parameters at variable $\mathrm{X} ; \mathrm{n}$ - the number of observations.

The table value of Fisher's criterion is $3.87\left(F_{t a b}=3,87\right)$ at the significance point $a=5 \%$ for the number of degrees of freedom $\mathrm{k} 1=1$ and $\mathrm{k} 2=300$. The calculation results by formula (11) determined the value $\mathrm{F}=2568,22$. Thus, it is considerably larger than $F_{t a b}$. The statistical significance of the parameters was confirmed.

Thus, the constructed model (9) is statistically significant according to Fisher's test. It explains more than $90 \%$ of the empirical data variability. The above allows concluding that the model has a sufficient level of adequacy. Figure 8 visualizes the forecast values for 85 days.

Figure 6 demonstrates that the new wave of COVID-19 disease is expected to be in mid-August-early September. The growing number of patients with COVID-19 require more hospital beds. It may result in new quarantine restrictions for the population and business. Therefore, it is necessary to carefully plan the preventive work to build collective immunity to the disease by mass vaccinations. 


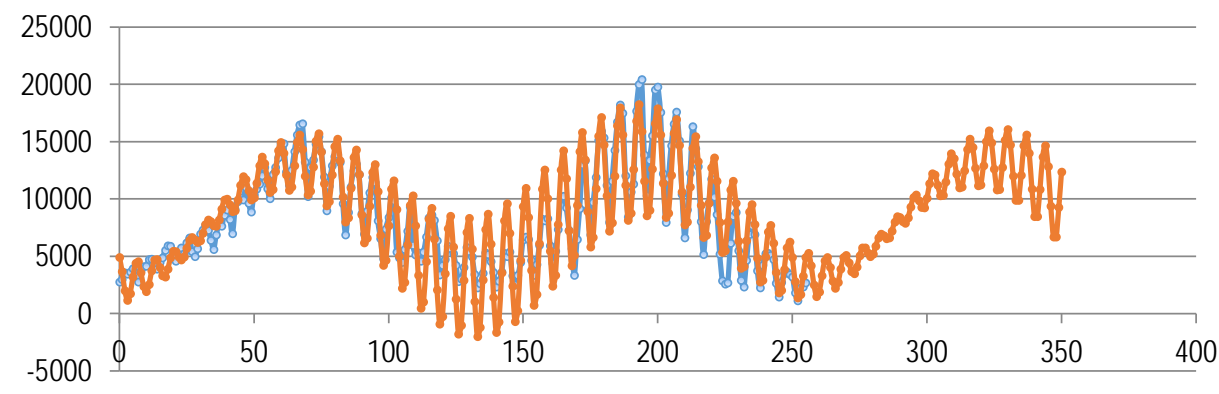

Figure 6. The forecast of COVID-19 pandemic progress in Ukraine

Sources: developed by the authors.

Conclusions. This study presents the theoretical analysis of the current scientific literature concerning the COVID-19 pandemic. The findings showed that scientists around the world had changed the direction of their interests towards pandemic issues. Notably, the research interest covers the investigations related to relationships between COVID-19 and different research areas. However, medicine and pharmaceutical are the priorities. The global economic crisis addresses economists worldwide to focus on estimating the magnitude of losses, exploring the possible options for mitigating the negative effects, and finding causal relationships of differentiated influence. Moreover, the special research focus is on forecasting future scenarios to timely prevent coronavirus spread.

Although the COVID-19 occurrence wasn't predicted, scientists mostly focus on forecasting future progress at the national and international levels.

The obtained results showed that the trigonometric and trend components are actively used for seasonal forecasting. This study involved the indicators such as the total number of coronavirus infected and deaths per unit time to model and predict the epidemiological phenomena. Notably, the above factors are interrelated. However, for further modeling, the indicator of the number of infected was chosen as more accurate. For analyzing the harmonic vibration, the Fourier series of observations were expanded to remove the trend component. The developed model was statistically significant.

The forecast showed that the new wave of coronavirus disease is expected to be in mid-August or early September. Therefore, it would cause an additional burden on hospitals in providing free beds. In turn, it may result in new quarantine restrictions. Notably, to avoid the lockdown and a new wave of coronavirus, it is necessary to provide the planned preventive measures to build collective immunity to the disease by mass vaccinations.

Moreover, it is appropriate to refrain from traveling, follow the recommendations for citizens by the Ministry of Health, avoid mass events, stimulate the public vaccination against the coronavirus.

Author Contributions: conceptualization, M. K.; methodology, R. M and M. P..; software validation, M. K. and R. M.; formal analysis, R. M. and M. P.; investigation, M. K.; resources, R. M.; data curation, R. M.; writing original draft preparation, M. K.; writing review and editing, M. K.; visualization, M. K.; supervision, M. K.; project administration, M. K.

\section{References}

Bond III, E. U., de Jong, A., Eggert, A., Houston, M. B., Kleinaltenkamp, M., Kohli, A. K., ... \& Ulaga, W. (2020). The Future of B2B Customer Solutions in a Post-COVID-19 Economy: Managerial Issues and an Agenda for Academic Inquiry. Journal of Service Research, 23(4), 401-408. [Google Scholar] [CrossRef]

Açikgöz, Ö., \& Günay, A. (2020). The early impact of the COVID-19 pandemic on the global and Turkish economy. Turkish journal of medical sciences, 50(SI-1), 520-526. [Google Scholar] 
Alkubaisy, A. (2020). Corporate Social Responsibility Practice in the Gulf Cooperation Council Countries amidst the COVID-19 Pandemic. Business Ethics and Leadership, 4(4), 99-104. [Google Scholar] [CrossRef]

Atalan, A. (2020). Is the lockdown important to prevent the COVID-19 pandemic? Effects on psychology, environment and economy-perspective. Annals of medicine and surgery, 56, 38-42. [Google Scholar] [CrossRef]

Boettke, P., \& Powell, B. (2021). The political economy of the COVID-19 pandemic. Southern Economic Journal, 87(4), 10901106. [Google Scholar] [CrossRef]

Brodeur, A., Gray, D., Islam, A., \& Bhuiyan, S. (2020). A literature review of the economics of COVID-19. Journal of Economic Surveys. [Google Scholar] [CrossRef]

Cutler, D. (2020). How Will COVID-19 Affect the Health Care Economy?. JAMA, 323(22), 2237-2238. [Google Scholar] [CrossRef

De Livera, A. M., Hyndman, R. J., \& Snyder, R. D. (2011). Forecasting time series with complex seasonal patterns using exponential smoothing. Journal of the American statistical association, 106(496), 1513-1527. [Google Scholar] [CrossRef]

Dutta, P., Dutta, U., Hasan, S., Sarkar, S., \& Sana, T. (2020). Educate, Empower And Protect People Through Timely Authentic Information: Explore How Bangladeshi Newspapers Response To COVID-19 Pandemic. SocioEconomic Challenges, 4(3), 93-103. [Google Scholar] [CrossRef]

Fanelli, D., \& Piazza, F. (2020). Analysis and forecast of COVID-19 spreading in China, Italy and France. Chaos, Solitons \& Fractals, 134, 109761. [Google Scholar] [CrossRef]

Gershon, D., Lipton, A., \& Levine, H. (2020). Managing COVID-19 Pandemic without Destructing the Economy. [Google Scholar] Hinrichs, G., \& Bundtzen, H. (2021). Impact of COVID-19 on personal insurance sales - Evidence from Germany. Financial Markets, Institutions and Risks, 5(1), 80-86. [Google Scholar] [CrossRef]

Power, K. (2020). The COVID-19 pandemic has increased the care burden of women and families. Sustainability: Science, Practice and Policy, 16(1), 67-73. [Google Scholar] [CrossRef]

Keliuotytè-Staniulènienè, G., \& Daunaravičiūtė, K. (2021). The global green bond market in the face of the COVID-19 pandemic. Financial markets, institutions and risks, 5(1), 50-60. [Google Scholar] [CrossRef]

Kobelev, N. (2000). Practical application of economic and mathematical methods and models. Text edition, 248.

Lopez, B. S., \& Alcaide, A. V. (2020). Blockchain, Al and IoT to Improve Governance, Financial Management and Control of Crisis: Case Study COVID-19. SocioEconomic Challenges, 4(2), 78-89. [Google Scholar] [CrossRef]

McKee, M., \& Stuckler, D. (2020). If the world fails to protect the economy, COVID-19 will damage health not just now but also in the future. Nature Medicine, 26(5). [Google Scholar] [CrossRef]

Nishi, A., Dewey, G., Endo, A., Neman, S., Iwamoto, S. K., Ni, M. Y., ... \& Young, S. D. (2020). Network interventions for managing the COVID-19 pandemic and sustaining economy. Proceedings of the National Academy of Sciences, 117(48), 3028530294. [Google Scholar] [CrossRef]

Papastefanopoulos, V., Linardatos, P., \& Kotsiantis, S. (2020). COVID-19: a comparison of time series methods to forecast percentage of active cases per population. Applied sciences, 10(11), 3880. [Google Scholar] [CrossRef]

Ozili, P., \& Arun, T. (2020). Spillover of COVID-19: Impact on the Global Economy (No. 99317). University Library of Munich, Germany. [Google Scholar] [CrossRef]

Ray, A. (2021). Containing Airborne Transmission of COVID-19 and Its Implications for Global Economic Recovery. Business Ethics and Leadership, 5(1), 81-88. [Google Scholar] [CrossRef]

Salinas, D., Flunkert, V., Gasthaus, J., \& Januschowski, T. (2020). DeepAR: Probabilistic forecasting with autoregressive recurrent networks. International Journal of Forecasting, 36(3), 1181-1191. [Google Scholar] [CrossRef]

Sandbrook, C., Gómez-Baggethun, E., \& Adams, W. M. (2020). Biodiversity conservation in a post-COVID-19 economy. Oryx, 1-7. [Google Scholar] [CrossRef

Taylor, S. J., \& Letham, B. (2018). Forecasting at scale. The American Statistician, 72(1), 37-45. [Google Scholar] [CrossRef]

Tommaso, F. D. (2020). The New Italian Legislation on Corporate Governance and Business Crisis. The Impact of COVID - 19 on SMEs and the Recent Rules to Mitigate the Effects. Financial Markets, Institutions and Risks, 4(4), 91-108. [Google Scholar] [CrossRef]

Tovmasyan, G., \& Minasyan, D. (2020). The Impact of Motivation on Work Efficiency for Both Employers and Employees also During COVID-19 Pandemic: Case Study from Armenia. Business Ethics and Leadership, 4(3), 25-35. [Google Scholar] [CrossRef] Worldometer. (2020). COVID-19 coronavirus pandemic. Retrieved from [Link]

Марія Каща, Сумський державний університет, Україна

Максим Палієнко, PhD, Італія

Роман Марченко, Сумський державний університет, Україна

Прогнозування перебігу пандемії COVID-19 з урахуванням сезонних коливань

Основною метою проведеного дослідження $є$ аналіз динаміки захворюваності на COVID-19 та побудова відповідного прогнозу, враховуючи попередні рівні інфікування громадян України. Систематизація літературних джерел та підходів до вирішення досліджуваної проблематики засвідчила стрімке зростання наукових публікацій, присвячених дослідженню COVID-19. Актуальність розв'язання наукової проблеми полягає в тому, що вірус SARS-CoV-2 трансформував всі сфрери 
життя у світі, спричинивши глибоку економічну кризу. Прогнозування перебігу пандемії в Україні здійснено в наступній логічній послідовності: 1) збір та аналіз статистичних даних; 2) перевірка на стаціонарність та періодичність часового ряду 3 використанням програмного забезпечення Statistica (portable); 3) побудова трендової компоненти 4) виявлення сезонної складової за допомогою швидкого перетворення Фур'є без урахування тренду, з використанням програмного забезпечення MathCAD (portable); 5) побудова загальної моделі, перевірка їі якості та адекватності; 6) побудова прогнозу та розробка рекомендацій. Методичним інструментарієм проведеного дослідження стали методи регресійно-кореляційного аналізу, тест Дікі-Фулера, декомпозиція адитивної моделі на циклічну та трендову складову, швидке перетворення Фур'є. Емпіричне дослідження проведено на основі панельних даних, сфоормованих з 22 січня 2020 року по 2 травня 2021 року. Об'єктом дослідження обрано населення України, яке було інфіковане коронавірусом у досліджуваний період. Дослідження емпірично підтверджує та теоретично доводить, що за умов збереження тенденцій перебігу пандемії в Україні та відсутності ретельно спланованої профілактичної роботи по запобіганню розповсюдженню вірусу, в середині серпня на початку вересня, може виникнути нова хвиля захворюваності. При цьому зростання навантаження на медичну сферу та збільшення летальних випадків серед населення, може спричинити впровадження нових обмежувальних карантинних заходів, що спричинить зупинку економіки та занепад малого та середнього бізнесу. Отже, необхідно спрямувати політику Уряду на ліквідування міфів про вакцинацію, для збільшення довіри до щеплення серед населення, що дасть можливість уникнути наступної хвилі захворювань.

Ключові слова: COVID-19, швидке перетворення Фур'є, стаціонарність, тест Дікі-Фулера, захворюваність, гармонійний аналіз, тренд-сезонна модель, прогноз. 